\title{
PATH ANALYSIS OF FACTORS ASSOCIATED WITH WORK PERFORMANCE OF HEALTH CENTER PERSONNEL IN CIAMIS, EAST JAVA
}

\author{
Latty Indriastuti'), Endang Sutisna Sulaeman²), \\ Eti Poncorini Pamungkasari²) \\ ${ }^{1)}$ Masters Program in Public Health, Universitas Sebelas Maret \\ 2)Faculty of Medicine, Universitas Sebelas Maret
}

\begin{abstract}
Background: Work performance was the outcome of all cumulative actions that the nurses' performs using their skills, abilities, and knowledge in providing health services to the community. Many factors influence work performance in health personnels. The purpose of this study was to examine factors associated with work performance of health center personnel using path analysis.

Subjects and Method: A cross sectional study was conducted in Ciamis, West Java, from November to December 2020. Total sample of 200 health personnel in health centers was selected by simple random sampling. The dependent variable was work performance. The independent variables were leadership style, work motivation, work satisfaction, education, patient, patient health treatment status, health worker status, tenure, perceived income, training, and type of human resources. The data were collected by questionnaire and analyzed using a multiple linear regression.

Results: Work performance in health personnel increased with good leadership style $(\mathrm{b}=6.09 ; 95 \% \mathrm{CI}=1.63$ to $3.18 ; \mathrm{p}<0.001)$, strong motivation $(\mathrm{b}=3.91 ; 95 \% \mathrm{CI}=0.73$ to 2.22; $\mathrm{p}<0.001)$, high work satisfaction $(\mathrm{b}=4.09 ; 95 \% \mathrm{CI}=0.78$ to $2.22 ; \mathrm{p}<0.001)$, high education $(\mathrm{b}=4.62 ; 95 \% \mathrm{CI}=0.99$ to $2.45 ; \mathrm{p}<0.001)$, inpatients $(\mathrm{b}=4.67 ; 95 \% \mathrm{CI}=1.00$ to $2.46 ; \mathrm{p}<0.001)$, health workers $(\mathrm{b}=4.62 ; 95 \% \mathrm{CI}=1.12$ to $2.77 ; \mathrm{p}<0.001)$, tenure $\geq 3$ years $(b=3.53 ; 95 \% \mathrm{CI}=0.59$ to $2.07 ; \mathrm{p}<0.001)$, good perceived income $(\mathrm{b}=4.14 ; 95 \%$ $\mathrm{CI}=0.87$ to $2.45 ; \mathrm{p}<0.001)$, had trained $(\mathrm{b}=4.96 ; 95 \% \mathrm{CI}=1.40$ to $3.23 ; \mathrm{p}<0.001)$, and civil servants ( $\mathrm{b}=3.97 ; 95 \% \mathrm{CI}=0.73$ to $2.16 ; \mathrm{p}<0.001)$.

Conclusion: Work performance in health personnel increases with good leadership style, strong motivation, high work satisfaction, high education, inpatients, health workers, tenure $\geq 3$ years, good perceived income, has trained, and civil servants.
\end{abstract}

Keywords: work performance, health personnel, community health center

\section{Correspondence:}

Latty Indriastuti. Masters Program in Public Health, Universitas Sebelas Maret. Jl. Ir. Sutami 36A, Surakarta 57126, Central Java. Email: lattyindria.drg@gmail.com. Mobile: +628999976544 . 